\title{
Motivation Factors of Consumers' Food Choice
}

\author{
Iraz Haspolat Kaya \\ Ankara University Institute of Biotechnology, Ankara, Turkey \\ Email: haspolatiraz@gmail.com
}

Received 5 February 2016; accepted 11 March 2016; published 14 March 2016

Copyright (C) 2016 by author and Scientific Research Publishing Inc.

This work is licensed under the Creative Commons Attribution International License (CC BY). http://creativecommons.org/licenses/by/4.0/

c) (i) Open Access

\begin{abstract}
Consumer perception of food products is a very complex phenomenon that is influenced by a wide range of characteristics. The major motivation for food science and nutrition should be sensual features, cost/price balance, and consumer health (sufficient/balanced nutrition). However, there are important differences between theory and reality. Food choice is a complex process influenced by a number of factors related to the product, the consumer, and the consumption context. The role of the consumer in determining the market success of a product is of maximum relevance. Consumer perceptions and preferences are in motion and in change. Understanding and analyzing consumers' motivation factors, perception and preferences are important both food industry and also governments. In this study, some of these factors were discussed and aimed to identify them with reasons.
\end{abstract}

\section{Keywords}

Food Consumer Choice, Organic Food, Natural Food, Healthy Nutrition

\section{Introduction}

Consumers may have different motivations for their food selection behaviours. Past research indicates that sensory appeal, healthiness, convenience, and price tend to be the most important factors that influence food choice [1]-[4].

Food choice is a complex process influenced by a number of factors related to the product (intrinsic and extrinsic properties), the consumer (e.g. knowledge, beliefs, attitudes), and the consumption context (e.g. occasion, cultural environment) [5]. The role of the consumer in determining the market success of a product is of maximum relevance [6]. The motivation for food choice may be influenced by an interest in health, weights concern, sensory pleasure, ideological reasons, convenience, price or familiarity [5]. Certainly, with the developments in 
technology, consumers also deal with the safe food production techniques and processes [7]. Over the past several years, investigators have assessed the concerns of consumers toward a variety of novel food technologies and other food-related safety issues [8].

\section{Food Safety and Health}

Directing consumers to safe food may be possible by determining their current perceptions and revealing and analyzing the factors affecting their motivation preferences. While there is a continuing work in the field of food technology for the development of new techniques and methods, to make food safer and trying to bring sustainability to the safe food supply, it is interesting to note that some consumers prefer products made of conventional methods and even in some cases they are prepared to pay higher prices for these products. Therefore, there is a need that the preferences and perceptions of consumers for each type of food should be determined by taking into account regional factors. While these studies are being executed, it must be remembered that consumer perceptions and preferences are in motion and in change e.g. in the late 1970s and early 1980s, consumers of food products very quickly became convinced that additives were dangerous and should be avoided. By the mid-1990s, interest in organic and natural foods had begun to rise and consumers also started becoming more aware of some of the potential benefits of additives. However, although consumers were aware of the benefits additives could deliver, the automatic assumption that additives were "bad" remained and consumers felt that additives should be reduced in our foods [9].

A number of demographic variables such as household income, number of children, gender, or age influence an individual's perception of risk [10]. Knowledge, beliefs and attitudes to food are the results of cultural background, eating habits established during childhood and the constant flow of information about food in daily life [5].

If consumers who have strongly negative attitudes towards chemicals no longer equated synthetic with toxic and natural with safe, consumers would be able to judge food hazards more appropriately [10]. In addition, this consumer opinion, also supported the opinion that has been said before; that the principal element of insecurity by consumers are thought to arise from the doubts against the applied process technology used for this food. Studies focusing on "production method" show that consumers tend to trust traditional and natural production methods more than methods associated with modernity and industry [11].

These negative attitudes towards additives may be associated with health concerns. From a technological point of view, food additives play an important role in the development of complex foods. However, the use of additives is an emotional topic, which provokes consumer concern [10]. Signalling production method has strong effects on consumer perceptions, especially if combined with specific regional origins. These results might indicate consumer distrust in more industrial production systems [11]. Additive names, sometimes difficult to pronounce for layman persons, give rise to the impression of unfamiliarity, which in turn results in perceptions of higher health risk [10].

\section{Novel Technologies}

The fact that the perceived potential risk of the technologies was the most important factor influencing consumer interest in their use, suggests that regardless of the actual risks of the technologies, the perceived risks are the critical determinants of the market success of these technologies [8].

Consumers tend to amplify the risk when a food or a technology is unknown, or to minimize the risk in familiar foods or home preparation [10]. From a consumer's perspective, innovation in foods may either imply real novelty or modifications of already existing products [12]. Lack of knowledge among consumers regarding innovative and emerging food technologies can serve as a major impediment to their acceptance [8]. In a qualitative study carried out with 12 focus groups in six European countries, Guerrero et al. [12] studied the acceptance of innovations in traditional products in terms of packaging, convenience, nutrition and sensory properties. These authors found that consumers are open to packaging and convenience-oriented innovations, on the condition that they do not modify the fundamental intrinsic characteristics of the product. Further, changes in sensory quality such as modified flavors are not welcome in traditional foods [12]. Corroborating these results, Vanhonacker et al. observed that European traditional food consumers welcome innovations that highlight the authenticity and origin of traditional foods and improve their shelf-life, but reject innovations that may affect the sensory properties of the product [13]. 
Credence cues addressing production methods affect liking, while expectations are also affected by information and influence hedonic ratings. Cues signaling traditional production seem to affect liking in a positive direction, whereas signals of "modernity" or "industrialized food" seem to have a negative impact on liking [11]. French consumers tend to reject the convenient packaging, which may reduce the traditional image of the cheese. Consumers have a higher acceptance for organic production than for conventional production of traditional cheese. The same trend is observed in Norway for special occasion consumption [13]. However, depending on the characteristics of the information about production method, the weight of the attributes may differ, and the number of papers found here was rather too limited to generalize consumer responses to a wide array of production-related factors, especially in novel production technologies [11].

\section{Natural and Organic Food Perception}

In the context of food safety, the public desires sufficient food, as well as more choices, year-round exotic and convenience foods, and the choice of organic or conventional, local or imported, value-added or traditional products. All of these parameters contribute value to the producer and benefits to the consumer but may be associated with varied and sometimes serious health risks [14]. Western developed world has attached the adjective "natural" to food products whenever possible [15]. Additionally, during the same period, organic food has acquired a growing consumer base. A large body of research has examined consumers' willingness to purchase and consume organic food [3] [16]-[18].

The attitudes toward "natural" in the developed world are dynamic and continuously changing [15]. For example, until the 19th century, "natural product" primarily referred to perishable products; the term later changed to be correlated with toxicity before the current, benevolent view was adopted [19]. Risk/safety, nutritional value, sacredness, and stewardship are among the issues that have influenced the perception of nature, and all of these factors are affected by social standing, education, and time period [15] [19].

The opinions about deteriorating in naturalness can especially be associated with the trend manifested towards organic food in all countries and communities. It has been reported that health is a stronger consideration compared with animal welfare and environment for consumers choosing organic dairy products [20]-[22], and it is likely, although not yet proven, that such health considerations would drive, at least partially, the choice of pasture based milk and dairy products as well [21]. When consumers make food purchasing decisions, health-related attributes of food have become as important as non-health related attributes such as taste or sensory appeal, familiarity, and convenience. This trend may contribute toward the growth of organic food sales because organic food is generally believed to have a higher nutritional content [23]. The credence of production method may contain different dimensions. On the one hand it may attribute to culture and tradition, meaning traditional production methods related to specific regions or cultures. As food systems have become more globalized and industrialized, consumers are increasingly aware of food from many different places, but as the "link to nature" has eroded, they show an interest in dedicated rather than generic products [11]. In a previous study, Ergonul (2013) noted that consumers generally reduce consuming high-fat foods, try to purchase safe foods free of hormones, pesticides and chemical residues, try to purchase packaged foods free of pathogenic microorganisms, try to consume foods free of toxic heavy metals, and they try to purchase much more organic foods for maintaining a healthier life in Turkey. Also, consumers' increasing demand for organic food may also be attributable to socially conscious consumerism [24]. More consumers are aware of the environmental, social, and economic impacts their choices may incur [23].

\section{Nutritional Value and Sensory Properties}

Consumers judge food quality on its sensory characteristics and on the nutritional value, health benefits, calorie content and vitamins, which determine the individual preferences for specific products [6] [25].

Taste is a major condition for acceptance, in addition to the trustworthiness of health claims [6] [26] [27]. According to Verbeke (2006) [27], numerous consumer studies have pointed to the primary role of taste in directing the food choices of consumers. This finding is in agreement with Hernandez-Carrion et al. (2011) who showed that the most important factors conditioning consumer food choice attitudes were that the item "tastes good," "is good value for money" and "keeps me healthy"; however, the "health" factor was not the most important factor [6]. The previous consumer studies show that the factor of taste is to be a critical driver of consumer perceptions of food quality and acceptance [8]. 


\section{Media}

According to the World Health Organisation (WHO), 2.2 million people worldwide die from food-borne diseases waterborne diseases every year combined [28]. Choosing what to eat and negotiating food risks has become a continuous challenge exacerbated by inaccurate expert/scientific knowledge [29]. True, clear, and understandable sources of knowledge are crucial to correctly orient consumers. However, one factor that should be considered when constructing this information source is the motivation for purchasing.

Consumers rely on the mass media for relevant information, and the media affects their purchase decisions [30]. The mass media are often a source of conflicting information about food, nutrition and health, resulting in beliefs and attitudes about the healthiness of foods that may diverge from the established knowledge [5]. Advertising and media publicity have been found to affect consumers' reallocations of expenditure across different food groups. Advertising often conveys a positive effect on certain food purchases. However, media publicity is not always positive [30].

\section{Age, Gender and Socio-Economic Statute}

Socio-economic and demographic features affected the consumers' knowledge and attitudes. Compared to elder consumers, the young consumers seem to be less health conscious and more biased in their healthiness expectations related to foods [5]. Some previous studies also note that higher education may be positively correlated with healthy dietary patterns [31]. Also, the awareness and knowledge of food hazards was higher among females and individuals with higher education and income [24] [32]. Higher socioeconomic groups seem to be more motivated by ideological factors, while lower socioeconomic groups focus on convenience, price and familiarity [33]. Also some studies indicate that gender affects a consumer's views of food consumption [34]-[36].

\section{References}

[1] Scheibehenne, B., Miesler, L. and Todd, P.M. (2007) Fast and Frugal Food Choices: Uncovering Individual Decision Heuristics. Appetite, 49, 578-589. http://dx.doi.org/10.1016/j.appet.2007.03.224

[2] Steptoe, A., Pollard, T.M. and Wardle, J. (1995) Development of a Measure of the Motives Underlying the Selection of Food: The Food Choice Questionnaire. Appetite, 25, 267-284. http://dx.doi.org/10.1006/appe.1995.0061

[3] Tobler, C., Visschers, V.H.M. and Siegrist, M. (2011) Eating Green. Consumers' Willingness to Adopt Ecological Food Consumption Behaviors. Appetite, 57, 674-682. http://dx.doi.org/10.1016/j.appet.2011.08.010

[4] Van Birgelen, M., Semeijn, J. and Keicher, M. (2009) Packaging and Proenvironmental Consumption Behavior: Investigating Purchase and Disposal Decisions for Beverages. Environment and Behavior, 41, 125-146. http://dx.doi.org/10.1177/0013916507311140

[5] Johanson, S.B., Naes, T. and Hersleth, M. (2011) Motivation for Choice and Healthiness Perception of Calorie-Reduced Dairy Products. A Cross-Cultural Study. Appetite, 56, 15-24. http://dx.doi.org/10.1016/j.appet.2010.11.137

[6] Hernandez-Carrion, M., Varela, P., Hernando, I., Fiszman, S.M. and Quiles, A. (2014) Persimmon Milkshakes with Enhanced Functionality: Understanding Consumers' Perception of the Concept and Sensory Experience of a Functional Food. LWT_Food Science and Technology, 62, 384-392. http://dx.doi.org/10.1016/j.lwt.2014.10.063

[7] Ergonul, B. (2013) Consumer Awareness and Perception to Food Safety: A Consumer Analysis. Food Control, 32, 461-471. http://dx.doi.org/10.1016/j.foodcont.2013.01.018

[8] Cardello, A.V., Schutz, H.G. and Lesher, L.L. (2007) Consumer Perceptions of Foods Processed by Innovative and Emerging Technologies: A Conjoint Analytic Study. Innovative Food Science and Emerging Technologies, 8, 73-83. http://dx.doi.org/10.1016/j.ifset.2006.07.002

[9] Brockman, C. and Beeren, C.J.M. (2011) Additives in Dairy Foods; Consumer Perceptions of Additives in Dairy Products. In: Fuquay, J.W., Fox, P.F. and McSweeney, P.L.H., Eds., Encyclopedia of Dairy Sciences, 2nd Edition, Academic Press, Washington DC, 41-48. http://dx.doi.org/10.1016/B978-0-12-374407-4.00003-0

[10] Varela, P. and Fiszman, S.M. (2013) Exploring Consumers' Knowledge and Perceptions of Hydrocolloids Used as Food Additives and Ingredients. Food Hydrocolloids, 30, 477-484. http://dx.doi.org/10.1016/j.foodhyd.2012.07.001

[11] Fernqvist, F. and Ekelund, L. (2014) Credence and the Effect on Consumer Liking on Food-A Review. Food Quality and Preference, 32, 340-353. http://dx.doi.org/10.1016/j.foodqual.2013.10.005

[12] Guerrero, L., Guardia, M.D., Xicola, J., Verbeke, W., Vanhonacker, F. and Zakowska-Biemans, S. (2009) Consumer-Driven Definition of Traditional Food Products and Innovation in Traditional Foods. A Qualitative Cross-Cultural Study. Appetite, 52, 345-354. http://dx.doi.org/10.1016/j.appet.2008.11.008 
[13] Almli, V.L., Naes, T., Enderli, G., Sulmant-Rosse, C., Issanchou, S. and Hersleth, M. (2011) Consumers’ Acceptance of Innovations in Traditional Cheese. A Comparative Study in France and Norway. Appetite, 57, 110-120. http://dx.doi.org/10.1016/j.appet.2011.04.009

[14] Todd ECD (2011) The International Risk Governance Council Framework and Its Application to Listeria monocytogenes in Soft Cheese Made from Unpasteurised Milk. Food Control, 22, 1513-1524. http://dx.doi.org/10.1016/j.foodcont.2010.07.020

[15] Rozin, P., Fischler, C. and Shields-Argeles, C. (2012) European and American Perspectives on the Meaning of Natural. Appetite, 59, 448-455. http://dx.doi.org/10.1016/j.appet.2012.06.001

[16] Lockie, S., Lyons, K., Lawrence, G. and Grice, J. (2004) Choosing Organics: A Path Analysis of Factors Underlying the Selection of Organic Food among Australian Consumers. Appetite, 43, 135-146. http://dx.doi.org/10.1016/j.appet.2004.02.004

[17] Shepherd, R., Magnusson, M. and Sjöden, P.O. (2005) Determinants of Consumer Behavior Related to Organic Foods. AMBIO: A Journal of the Human Environment, 34, 352-359. http://dx.doi.org/10.1579/0044-7447-34.4.352

[18] Squires, L., Juric, B. and Cornwell, T.B. (2001) Level of Market Development and Intensity of Organic Food Consumption: Cross-Cultural Study of Danish and New Zealand Consumers. Journal of Consumer Marketing, 18, 392-409. http://dx.doi.org/10.1108/07363760110398754

[19] Stanzian, A. (2008) Defining "Natural Product” between Public Health and Business, 17th to 21st Centuries. Appetite, 51, 15-17. http://dx.doi.org/10.1016/j.appet.2008.02.007

[20] Bourne, D. and Prescott, J. (2002) A Comparison of the Nutritional Value, Sensory Qualities, and Food Safety of Organically and Conventionally Produced Foods. Critical Reviews in Food Science and Nutrition, 42, 1-34. http://dx.doi.org/10.1080/10408690290825439

[21] Capuano, E., Gravink, R., Boerrigter-Eenlig, R. and van Ruth, S.M. (2015) Fatty Acid and Triglycerides Profiling of Retail Organic, Conventional and Pasture Milk: Implications for Health and Authenticity. International Dairy Journal, 42, 58-63. http://dx.doi.org/10.1016/j.idairyj.2014.11.002

[22] Hermansen, J.E. (2003) Organic Livestock Production Systems and Appropriate Development in Relation to Public Expectations. Livestock Production Science, 80, 3-15. http://dx.doi.org/10.1016/S0301-6226(02)00313-5

[23] Lee, H.J. and Yun, Z.S. (2015) Consumers' Perceptions of Organic Food Attributes and Cognitive and Affective Attitudes as Determinants of Their Purchase Intentions toward Organic Food. Food Quality and Preference, 39, $259-267$. http://dx.doi.org/10.1016/j.foodqual.2014.06.002

[24] Shafie, F.A. and Rennie, D. (2012) Consumer Percepions towards Organic Food. Procedia-Social and Behavioural Sciences, 49, 360-367. http://dx.doi.org/10.1016/j.sbspro.2012.07.034

[25] Norton, T. and Sun, D.W. (2008) Recent Advances in the Use of High Pressure as an Effective Processing Technique in the Food Industry. Food Bioprocess Technology, 1, 2-34. http://dx.doi.org/10.1007/s11947-007-0007-0

[26] Cox, D.N., Koster, A. and Russell, C.G. (2004) Predicting Intentions to Consume Functional Foods and Supplements to Offset Memory Loss Using an Adaptation of Protection Motivation Theory. Appetite, 43, 55-64. http://dx.doi.org/10.1016/j.appet.2004.02.003

[27] Verbeke, W. (2005) Consumer Acceptance of Functional Foods: Socio-Demographic, Cognitive and Attitudinal Determinants. Food Quality and Preference, 16, 45-57. http://dx.doi.org/10.1016/j.foodqual.2004.01.001

[28] Food Standards Agency (2011) The FSA Foodborne Disease Strategy 2010-15. Food Standards Agency, London.

[29] Shaw, A. (1999) "What Are 'They’ Doing to Our Food?”: Public Concerns about Food in the UK. Sociological Research Online, 4. http://dx.doi.org/10.5153/sro.329

[30] Yadavali, A. and Jones, K. (2014) Does Media Influence Consumer Demand? The Case of Lean Finely Textured Beef in the United States. Food Policy, 49, 219-227. http://dx.doi.org/10.1016/j.foodpol.2014.08.002

[31] Bus, A.E.M. and Worsley, A. (2003) Consumers' Health Perceptions of Three Types of Milk: A Survey in Australia. Appetite, 40, 93-100. http://dx.doi.org/10.1016/s0195-6663(03)00004-7

[32] Stobelaar, D.J., Casimir, G., Borghuis, J., Marks, I., Meijer, L. and Zebeda, S. (2006) Adolescents’ Attitudes towards Organic Food: A Survey of 15- to 16-Year Old School Children. International Journal of Consumer Studies, 31, 349356. http://dx.doi.org/10.1111/j.1470-6431.2006.00560.x

[33] Crossley, M.L. and Khan, S.N. (2001) Motives Underlying Food Choice. Dentists, Porters and Dietary Health Promotion. British Dental Journal, 191, 198-202. http://dx.doi.org/10.1038/sj.bdj.4801139a

[34] Bellows, A.C., Alcaraz, V.G. and Hallman, W.K. (2010) Gender and Food, a Study of Attitudes in USA toward Organic, Local, U.S. Grown and GM-Free Foods. Appetite, 55, 540-550. http://dx.doi.org/10.1016/j.appet.2010.09.002

[35] Beardsworth, A., Bryman, A., Keil, T., Goode, J., Haslam, C. and Lancashire, E.İ. (2002) Women, Men, and Food. The Significance of Gender for Nutritional Attitudes and Choices. British Journal of Food, 104, 470-491. 
http://dx.doi.org/10.1108/00070700210418767

[36] Robinson, R. and Smith, C. (2003) Associations between Self-Reported Health Conscious Consumerism, Body-MassIndex and Attitudes about Sustainably Produced Foods. Agriculture and Human Values, 20, 177-187.

http://dx.doi.org/10.1023/A:1024017610510 